\title{
EMERGING TENDENCY OF BRANDS UTILIZATION AND ITS IMPACTS ON LIFE SATISFACTION OF UNIVERSITY STUDENTS \\ Abd ul Waheed ${ }^{1}$, Iqra Almas ${ }^{2}$, Laila Shafi ${ }^{3}$, Umme Kalsoom ${ }^{4}$, Kanwal Yasmin ${ }^{5 *}$
}

${ }^{1}$ Associate Lecturer, Department of Sociology, The Islamia University of Bahawalpur, Pakistan; ${ }^{2}$ Associate Lecturer, Department of Sociology, The Islamia University of Bahawalpur, Pakistan; ${ }^{3}$ M.Phil., Scholar, Department of Sociology, University of Sargodha, Pakistan; ${ }^{4}$ M.Phil., Scholar, Department of Sociology, University of Sargodha, Pakistan;

${ }^{5 *}$ M.Phil., Scholar Department of Education, National University of Modern Languages (NUML), Islamabad, Pakistan. Email: ${ }^{1}$ abdulwaheed@iub.edu.pk, ${ }^{2}$ iqra.almas@iub.edu.pk, ${ }^{3}$ lailashafi.ps13@gmail.com, ${ }^{4}$ ummekalsoom369@gmail.com, ${ }^{*}$ sadaf_hrl@yahoo.com

Article History: Received on $5^{\text {th }}$ July 2021, Revised on $18^{\text {th }}$ July 2021, Published on $19^{\text {th }}$ July 2021

\begin{abstract}
Purpose of the study: This research examines the emerging tendency of brands utilization and its impacts on the life satisfaction of university students.

Methodology: It is a quantitative study where a survey research method has been used, and for data collection, the questionnaire has been prepared. Demographic variables like area, age, gender, qualification, and location are also included. A sample of 385 students was selected by using the proportional allocation method. Statistical analysis for data was done through SPSS software. Researchers used a linear regression analysis test to find out the impacts of brand utilization on the life satisfaction of university students.
\end{abstract}

Principal Findings: The findings of the study show that life satisfaction has a significantly negative correlation with brand utilization. Research also indicates that most purchased items were branded clothing and cosmetic products.

Application of the study: This paper will be helpful to understand brand utilization and its impacts on youth's life satisfaction.

Novelty/Originality of this study: To analyze the growing tendency of luxury and brands products, researchers determined to check the impacts of branded products on life satisfaction levels. To examine the impacts of brand utilization, this research focused on four Pakistani universities and the life satisfaction level of students has bees examined.

\section{Keywords: Brands, Utilization, Impacts, Students, Life Satisfaction.}

\section{INTRODUCTION}

The brand is seen as a unique, universal, and special sign that may indicate the producer of brand products and it may vary from one brand to another. The majority of the population have an addiction to brand consumption. (Viswanathan \& Rosa 2010). Historically, human beings have been trying to satisfy themselves with the provision of the superior product. The ancient civilizations were abundant in material power. The upper classes always adorn themselves with costume jewellery, which is formed by unique apparatus. A huge amount of resources were devoted to elaborating and sustaining difficult systems of text, calenderer system, prediction, and many other spiritual traditions. The power was "symbolized" on which temple platforms, throne rooms, processional habits, royal tombs, and palaces were established (Butgel Tunali, S. 2016).

According to the evolutionary viewpoint, the individual priority for brand consumption is derived from a general trend of showing personality. The evolutionary explanation of brand consumption not only needs evidence of psychological adaptations in the minds of consumers but also the wealth that generates psychological adaptations in the minds of spectators. In modern times, social mobility is more incredible than earlier. Individuals are becoming highly brand conscious. Well-known brand labels on outfits, footwear, eatables, and electronic pleasure to the conspicuous customers. They come to be more "self-conscious", which increases the attraction in them to track the trend of brand competition. Significant numbers of individuals in the world are reliving globally spread consumer images, signs, and preferences that flow mainly from the West. (Akaka et al., 2010)

Globalization has many opportunities and hurdles for worldwide dealers. In this age, import and export of goods seem to much economical. Every business hub tries to generate new designs and specifications in the products so they can quickly fascinate their customers. Many Western companies are investing and trading in Asian regions because there was less population, and the consumer rate is meagre. There is also notable that all over the world, people prefer the branded products over locally produced items. (Gürhan-Canli et al., 2018).

Meanwhile, Pakistan also accepts the international traders and their products to be delivered in Pakistan. And the desire and adoption for international brands seem so high in the youth. There is always a trendsetter, and in Pakistan, our youngsters are the trendsetters in this perspective. Youth admires and is impressed by the Western products and fascinate to consume them. Cultural diffusion is caused by the adoption of brands as well. Terms and conditions for buying international products and some strict policies may affect the buying ratio. Most of the time, the consumers buy those 
expensive products only for consumption; on the other hand, it is also performed for the satisfaction and acceptance in society by other people (Laroche et al., 2003)

Different age groups have different tastes in the selection of brands. It is observed that our youth is very much energetic to adopt new trends and new products with latest varieties. They are good to go to buy the accessories like electric gadgets, clothes, and shoes, etc. The universality and unique looks of adopting brands also seem so high in youth. Complexities seem high by brands adoption our youth is less skillful but by looks, they are up to the mark. In the same way, they have less leadership and mentorship qualities. They tried to adopt other cultures, and it shows much diversity, which is not acceptable for our society and culture (Ahmad et al., 2013).

\section{The motivation of the study}

In this research, readers would be able to acquire actual knowledge about the emerging tendency of brands utilization and the life satisfaction level of students. According to many students, by wearing brands clothes, they feel satisfied in their lives, that's why they purchased branded items. This research is based on the analysis through SPSS software and the researcher have organized, analyze the available evidence to conclude impacts.

\section{Objectives of Research}

The main objective of this research is to explore the emerging tendency of brands utilization and its impacts on the life satisfaction of university students.

\section{REVIEW OF LITERATURE}

In this study, many research results, causes, and effects of variables have been examined related to the topic. It depicts the attitude of the customers regarding their taste of products. Meanwhile, (Veblen 1899) most of the time, the studies show that people adopt the branded products as a symbolic interaction among them and status in contemporary society. Most famous brands in electric gadgets like blueberry, apple, and Nike's logo are the representatives of some social classes. Most of the customers expect some good or less price for the products as all decent brands are much more expensive. Most of them want to go for marts to get cheaper products and fulfill their desires. People do invest some extra money on high-end products and some up to the mark high brands (Charles et al., 2009).

\section{Brands Utilization}

There are many brands which are so much luxury and expensive as well. So it highlights the clear conflict among the upper-class societies and the lower-class societies consumers. The costs of the branded products play a vigorous role in this difference. The luxury life and how to look sophisticated in front of society's people is only possible if they afford or consume the high-end brands. The level of satisfaction can be measured by the tendency of adaptation of brands like cars, dresses, shoes, electrical gadgets, and other daily life products. They relate their level of satisfaction to the affordance of the high and expensive brands (Koehn, 2001).

\section{Life satisfaction approach}

The level of satisfaction of youth towards life is interlinked with many other perspectives of life either they are mental, social, physical, or personal. Their behaviours always depict their situations in life. Their productivity in life is dependent on their satisfaction levels (Proctor et al., 2009). Customarily, youth and their life satisfaction levels can also be measured by their positive or negative psychological behaviour and feelings. There has been a lot of work on the importance of proper socialization and purposeful performance of youth in the past few years. (Greenspoon and Saklofske 2001).

A person who is fully satisfied in life could be assessed completely by his/her mental evaluation (Proctor 2014), and it is considered as the best and developed meter to measure the positivity in functioning and well-being; of the individual (Suldo et al., 2006).

Life satisfaction level is a specific or general, and wide range of contexts (Huebner 2009). Usually, the specific and general context of life satisfaction is generally reported by individuals. General represents the overall satisfaction while in another context it represents concerning life and related satisfaction (Proctor et al., 2009). Generally, in the one dimension of, people set by their measures toward life satisfaction (Huebner 2009), and life satisfaction by social and psychological bonding and also treat and normalize the relation of both the situation and actions (Proctor and Linley 2014).

In addition, facilitation toward the high satisfaction level of life and good care should be provided in the situations of anxiety and stress and their behaviour modes (McKnight et al. 2002). Moreover, the barriers toward life satisfaction have so many adverse effects, which may cause anxiety and stress and helps to damage the psyche of an individual. In the case of two youngsters first one has a satisfying life, and he didn't need to express hyper behavior, on the other hand, the teenager with a less satisfying life show more aggression and anxiety by their behavior (Valoisetal 2010). 
It is hard to get satisfaction in teen ager's life. Still, the family and environment played a vital role as we can see the structure of family and the relationship of kids with parents and societal support and issues in family as well as the company of friends (Milevsky et al., 2007).

Life satisfaction of youth also has negative relation with the disorder in eating called "anorexia and bulimia nervosa" (Halvorsen and Heyerdhal 2006), i.e. bad behaviors of eating and obese condition. (Valois et al., 2003) said that there are many wrong conceptions among youth regarding their satisfaction and body weight. They use so many inappropriate medications to maintain their weight, and it is practised among American youngsters. In the same way (Saluoumi and Polurde 2010), talked about the Canadian youth that they are not satisfied with their bodies and weight and they do possible ways to be in shape and do all the things which can control the weight by doing smoking and less eating this may cause the lack of life satisfaction.

Grossman and Rowat 1995 worked on Canadian youth; according to his lack of socialization by parents and deprived family conditions also play a vital role toward the interests of youth. In the same way (Winkelmann 2006) talked about the German youth and their trends. The inappropriate styles of living and broken family conditions placed a huge harmful impact on the life of youth. In addition by setting fixed and rigid rules and regulations and give them highprofile punishments also caused them to adopt wrong patterns to gain comfortable life.

In the same way (Paxton et al., 2006), highlighted the significance among the teenagers and their purposeful relations and their level of satisfaction and interest in society. In addition, the conceived youngsters have more depression and anxiety in their life and less academic progress. As well as the other remaining teenagers who did not have such sexual relations not conceived have more satisfaction and good grades in their studies (Powdthavee and Vignoles 2008). So much fast and bold bond between youth playing a vital role to become closer either it is social or physical (Olivia and Arranz 2005)

People regularly appear to be more joyful if they gain more than the people they match themselves. Indeed, luxury consumption may reduce individual's happiness since they trust it, gives them a higher status, inside their own reference groups as well as inside their aspiratory gatherings. Some researches show a positive relationship between status consumption and wellbeing. These indifferences show that luxury consumption may definitely influence the satisfaction of life and positive impacts, yet it may negatively influence (Hartmann et al., 2012).

Practice and adoption of organic products may be interlinked positively to life satisfaction. It may reason to give more strength and power to the people, as the nature has no artificial and complexities. (Chang, C et al., 2020). The investigation of happiness information proves of the degree to which living conditions are unfavourable or positive favourable to the individuals. For illustration, environmental degradation might be reflected in lower well-being. This line of empirical study opens up another methodology for the valuation of public products. The advantages got from general products are innately hard to quantify because they are not legitimately traded in business sectors. In any case, public organizations specifically have an interest in the estimation of inclinations for public products. Progressively, they are legally necessary to give cost advantage analysis to assess the social desirability of government programs. The financial matters of happiness give a corresponding promising technique that maintains a strategic distance from a portion of the significant challenges inborn in past ways to deal with available esteem products. It is known as the Life Satisfaction Approach (Frey et al., 2010).

In Pakistan the current age where the trend of brand utilization is growing day by day. It is the easiest way to find out about the modern lifestyle. As well as the international investors finding their way towards the new investment horizons. This plays a vital role in the changing lifestyle and economic condition of brands and consumers the same way (Abbas et al., 2016). There is also seen that Muslim consumers are so much conscious about the selection of brand regarding the halal and haram concept. Their commitment to religion make them more selective and conscious. (Usman et al., 2021). Electric gadgets with known brand tags are adopted by youth and they feel superior by adopting advancement. Materialism and ethnocentrism are caused by brand consumption as well (Sithole et al., 2020). Mental satisfaction may interlink with social status. And it may vary from person to person by their differences in adopting styles and how they contribute to the economy of the retailer and consumers (Maggioni et al., 2019). Consumers are becoming more conscious of choosing brands in eating, wearing, and other utilization. They relate it with the quality of life. (Mrad and Cui 2020)

\section{Hypothesis}

Brand utilization has a significant association with life satisfaction.

\section{METHODOLOGY}

It was descriptive research; by using a questionnaire as a tool; the emerging tendency of brands utilization and its impact on university students was examined. The population of the study was the students of three Universities located in Punjab Province (University of Sargodha, Bahauddin Zakriya University Multan, and Punjab University Lahore) and one from the Capital City of Pakistan, i.e. Quaid-e-Azam University Islamabad. The data was collected from respondents through a convenient sampling method. 


\section{Sampling}

The total number of registered students at four universities are shown in table 1.

Table 1: Total Registered Students

\begin{tabular}{lll}
\hline Sr. No & Universities & Registered Students \\
\hline 1 & University of Sargodha & $\mathbf{2 8 3 4 2}$ \\
\hline 2 & Bahauddin Zakariya University & $\mathbf{3 5 0 0 0}$ \\
\hline 3 & Punjab University & $\mathbf{4 5 0 0 0}$ \\
\hline 4 & Quaid-e-Azam University & $\mathbf{1 3 0 0 0}$ \\
\hline & Total & $\mathbf{1 2 1 3 4 2}$ \\
\hline
\end{tabular}

\section{Sampling Technique}

Researchers used the Raosoft sampling calculator.

The total " 385 " samples have been selected for this study.

"Portional Allocation Method" has been used for obtaining the required sample.

$$
\left(n_{i}=\frac{\mathrm{N}_{\mathrm{h}}}{N} \times \mathrm{n}\right)
$$

Where

( $n_{i}=$ Sample distributed in specific university).

$\left(\mathrm{N}_{\mathrm{h}}=\right.$ Sample used for several registered students in a specific university).

( $\mathrm{N}=$ Sample used for total registered students of all universities).

$(\mathrm{n}=$ Total selected sample).

(Proportional Distribution (University of Sargodha)

$\left(n_{i}=28342 / 121342 * 385\right)$

$\left(n_{i}=90\right)$

(Proportional Distribution (BahauddinZakariya University)

$\left(n_{i}=35000 / 121342 * 385\right)$

$\left(n_{i}=111\right)$

(Proportional Distribution (Punjab University)

$\left(n_{i}=45000 / 121342 * 385\right)$

$\left(n_{i}=142\right)$

(Proportional Distribution (Quaid-i-Azam University)

$\left(n_{i}=13000 / 121342 * 385\right)$

$\left(n_{i}=42\right)$

Thus the distribution of sample university-wise as appended below in table 2 .

Table 2: University wise distribution of sample

\begin{tabular}{lll}
\hline Sr. No & Universities & Sample selected \\
\hline 1 & University of Sargodha & $\mathbf{9 0}$ \\
\hline 2 & Bahauddin Zakariya University & $\mathbf{1 1 1}$ \\
\hline 3 & Punjab University & $\mathbf{1 4 2}$ \\
\hline 4 & Quaid-i-Azam University & $\mathbf{4 2}$ \\
\hline
\end{tabular}

Data was analyzed by using SPSS software.

Analysis

Table 3: Regression analysis of brands utilization and life satisfaction 


\begin{tabular}{|c|c|c|c|c|}
\hline & B & Std. Error & Beta & \\
\hline Constant & 24.048 & 0.662 & & 36.332 .000 \\
\hline Brand Consumption & -0.182 & 0.089 & -0.104 & -2.0400 .042 \\
\hline $\mathrm{R}$ & 0.104 & & & \\
\hline Adj. R & 0.008 & & & \\
\hline $\mathrm{R}^{2}$ & 0.011 & & & \\
\hline
\end{tabular}

This table shows the relationship between brands utilization and life satisfaction. The table presented that the brand utilization and life satisfaction has adverse relation. The model is fitted as the $R^{2}=0.011$, and $F=4.16$ value revealed this. Further, the analysis showed that if one unit of brand utilization is increased then the life satisfaction decreased to 0.18 units. Value $(-0.182)$ between life satisfaction and brand utilization demonstrates that both variables are negatively correlated. Brand utilization was used as the independent variable in the test, and life satisfaction as the dependent variable in this test.

\section{Monthly Shopping items}

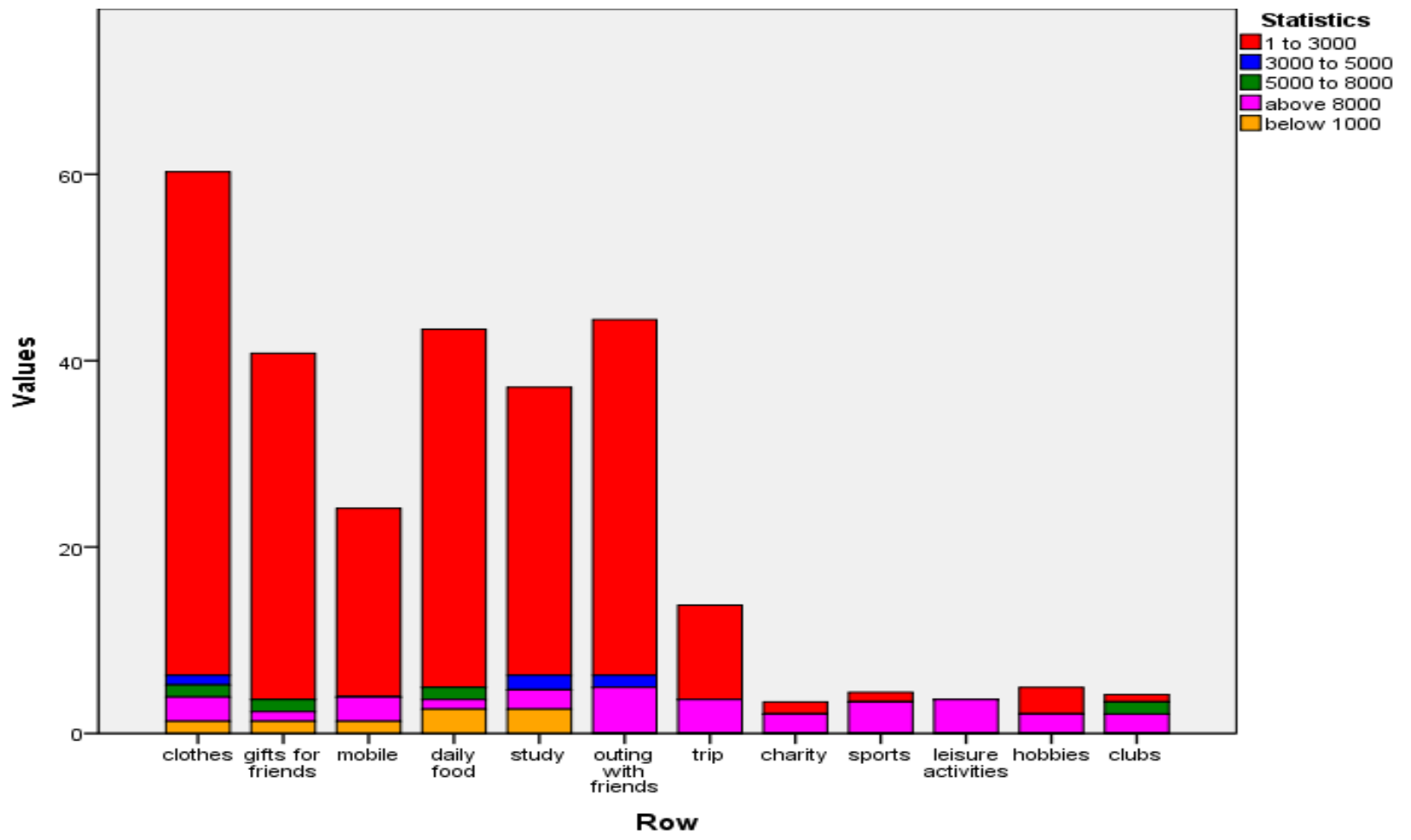

Figure 1: Monthly shopping items

In this graph the frequency distribution the students demonstrated in the context of "Monthly Shopping Items". Categories of money are also demonstrated in this graph, which they consumed on purchase of different branded items. This graph demonstrates that $54 \%$ of students spent 1 to 3000 rupees on clothes every month, only $1.29 \%$ of students spent more than 8000 rupees on clothes every month. This graph demonstrates that only $37.1 \%$ of students spent 1 to 3000 rupees on gifts for friends. This graph further demonstrates that only $20.3 \%$ of students spent 1000 to 3000 rupees on mobile every month. This graph further demonstrates that only $38.4 \%$ spent 1 to 3000 rupees on daily food. This graph further demonstrates that only $30.9 \%$ spent 1 to 3000 rupees on the study and only $2.1 \%$ spent more than 8000 rupees on the study. This graph further demonstrates that only $38.2 \%$ spent 1 to 3000 rupees on an outing with friends and only $4.9 \%$ spent more than 8000 rupees on an outing with friends. This graph further demonstrates that only $10.1 \%$ spent 1 to 3000 rupees on the trip and only 3.6\% spent more than 8000 rupees on the trip. This graph further demonstrates that only $1.3 \%$ spent 1 to 3000 rupees on charity and only $2.1 \%$ spent more than 8000 rupees on charity. This graph further demonstrates that only $1.0 \%$ spent 1 to 3000 rupees on sports and only $3.4 \%$ spent more than 8000 rupees on sports items every month. This graph further demonstrates that only $3.6 \%$ spent more than 8000 rupees on leisure activities items every month. This graph further demonstrates that only $2.9 \%$ spent 1 to 3000 rupees on their hobbies and only $2.1 \%$ spent more than 8000 rupees on their hobbies every month. This graph further demonstrates that only $0.8 \%$ spent 1 to 3000 rupees on sports and only $2.1 \%$ spent more than 8000 rupees in clubs every month. The significant findings of the graph indicate that the majority of students, i.e., (54.0) \% spent money on purchasing clothes. This graph demonstrates that most students are tended to purchase apparel products instead of others items like clubs, 
hobbies, leisure activities, sports, charity, trips, mobile, outgoing with friends, study, gifts for friends. This graph further demonstrates that most students spent less money on charity and leisure activities.

\section{Life Satisfaction}

\begin{tabular}{|c|c|c|c|c|c|}
\hline Scale & $\begin{array}{l}\text { Strongly } \\
\text { Agree }\end{array}$ & Agreed & Neutral & Disagreed & $\begin{array}{l}\text { Strongly } \\
\text { disagreed }\end{array}$ \\
\hline I am satisfied about everything in my life & $1.3 \%$ & $59.5 \%$ & $22.9 \%$ & $15.3 \%$ & $1.0 \%$ \\
\hline I don't feel life is going in right direction & $1.3 \%$ & $17.7 \%$ & $15.8 \%$ & $58.2 \%$ & $7.0 \%$ \\
\hline Conditions of my life are not excellent & $1.0 \%$ & $28.8 \%$ & $15.6 \%$ & $46.0 \%$ & $8.6 \%$ \\
\hline $\begin{array}{l}\text { If I could live my life forever, I would change } \\
\text { almost nothing }\end{array}$ & $0.0 \%$ & $34.8 \%$ & $13.5 \%$ & $\mathbf{4 7 . 8 \%}$ & $3.9 \%$ \\
\hline In most ways my life is close to my ideal & $1.3 \%$ & $38.4 \%$ & $25.2 \%$ & $\mathbf{3 3 . 8 \%}$ & $1.3 \%$ \\
\hline $\begin{array}{l}\text { So, for I have gotten the important thing I want in } \\
\text { life }\end{array}$ & $1.3 \%$ & $48.3 \%$ & $14.8 \%$ & $32.2 \%$ & $3.4 \%$ \\
\hline I always feel sadness & $2.6 \%$ & $28.6 \%$ & $9.6 \%$ & $54.3 \%$ & $4.9 \%$ \\
\hline I always contentment & $2.6 \%$ & $58.2 \%$ & $20.5 \%$ & $16.4 \%$ & $2.3 \%$ \\
\hline I am a healthy person & $2.6 \%$ & $68.8 \%$ & $9.6 \%$ & $16.4 \%$ & $2.6 \%$ \\
\hline I feel life is good & $2.6 \%$ & $66.5 \%$ & $11.4 \%$ & $18.2 \%$ & $1.3 \%$ \\
\hline I feel fully mentally alert & $2.6 \%$ & $46.5 \%$ & $22.1 \%$ & $27.5 \%$ & $1.3 \%$ \\
\hline I feel I am successful in life & $1.3 \%$ & $55.6 \%$ & $16.4 \%$ & $25.5 \%$ & $1.3 \%$ \\
\hline
\end{tabular}

This table demonstrates frequency distribution according to "Life Satisfaction". The life Satisfaction scale has been used in this table to determine life Satisfaction levels among the students. The students responded according to their life satisfaction level. The value of the question also demonstrates like "I am satisfied with everything in my life" most of the students, i.e. (59.5) \% agreed on this question. In comparison, $22.9 \%$ remained neutral and $15.3 \%$ have disagreed, and only $1.0 \%$ strongly agreed. It further demonstrates the values of the statement "I don't feel life is going in the right direction" most of the students i.e. (58.2) \% disagreed with the statement. In comparison, $15.8 \%$ remained neutral, and $17.7 \%$ agreed. Value of this statement also demonstrated "Conditions of my life are not excellent" mostly students, i.e., (46.0) \% ware disagreed, with this statement. In comparison, $15.6 \%$ remained neutral. Only $28.8 \%$ agreed. It also demonstrates the value of this statement "If I could live my life forever I would change almost nothing" most of the students, i.e. (47.8) \% has disagreed. In comparison, $13.5 \%$ remained neutral. Only $34.8 \%$ agreed. It also demonstrates the value of this statement "In most ways, my life is close to my ideal" most of the students, i.e. (38.4) \% agreed. In comparison, $25.2 \%$ remained neutral. Only $33.8 \%$ disagreed. It also demonstrates the value of this statement "So for I have gotten the important thing I want in life" most of the students, i.e. (48.3) \% agreed. In comparison, $14.8 \%$ showed a neutral response and $32.2 \%$ disagreed. It also demonstrates the value of this statement "I always feel sadness" most of the students, i.e. (54.3) \% opposed the statement. In comparison, 9.6\% showed a neutral response. Only $28.6 \%$ agreed. It also demonstrates the value of this statement "I always contentment" most of the students, i.e. (58.2) \% agreed. In Comparison, 20.5\% showed a neutral response. Only 16.4\% disagreed. It also demonstrates the value of this statement "I am a healthy person" most of the students, i.e. (68.8) \% agreed. In comparison, 9.6\% showed a neutral response. Only $16.4 \%$ disagreed. It also demonstrates the value of this statement "I feel life is good" most of the students, i.e. (66.5) \% agreed. In comparison, $11.4 \%$ showed a neutral response. Only $18.2 \%$ disagreed. It also demonstrates the value of this statement "I feel fully mentally alert" most of the students, i.e. (46.5) \% agreed. In comparison, $22.1 \%$ showed a neutral response. Only $27.5 \%$ disagreed. It also demonstrates the value of this statement "I feel I am successful in life" most of the students, i.e. (55.6) \% agreed. In comparison, 16.4\% showed a neutral response and only $25.5 \%$ disagreed.

\section{DISCUSSIONS}

The study mainly focused on the growing tendency of brands utilization and its effects on the life satisfaction of university students. The results show that brands utilization have adverse relations with the life satisfaction of university students (Proctor, C. 2014), in this study the researchers selected a linear regression analysis test for better interpretation of results.

The results show that life satisfaction is not dependent on brand utilization and the students who used branded products are not satisfied. It's meant that branded products are not valuable in their lives. They can get satisfaction by using local products. No doubt, brand products have significant demands on a global level, but these products cannot enhance the satisfaction level of people. Branded products are expensive and the majority of people can't afford these products on daily basis. Brands products of good quality and multiple choices, yet are unable to satisfy people (Powdthavee \& Vignoles 2008). Growing demands of luxury brands may also create depression or anxiety among youth who cannot afford branded products (McKnight et al., 2002). This research was conducted on students of Universities, the majority of students in this research belongs to the middle class. Therefore, they are unable to afford these expensive brand products. Students in this study went occasionally went shopping; It means that they don't have enough resources to buy brand products on a daily, weekly, or monthly basis. Sometimes, brand products create anxiety or depression among the 
youth, For instance, those who afford branded product creates inferiority complex for those who can't afford the branded product. Therefore, in this context brands consumption is negatively correlated with the life satisfaction of youth.

The term popular is not dependent on brand adoption. According to the students of universities, they don't believe that utilization of branded and high-end products make them more famous or popular in front of others students. They also don't think that wearing brands lead them toward a more respectable figure in society. It shows entirely a negative relation with brand adoption and respect factor.

\section{CONCLUSION}

The recent research mainly focused on the growing tendency of brands utilization and its effects on the life satisfaction of university students. In this study, the researcher used a convenient sampling technique for data collection. The tool of data collection was a questionnaire. In this study, the researcher used the Raosoft calculator for sampling distribution. The findings of the present study showed the negative relationship of brand utilization with the life satisfaction of youth. Findings showed that most students get pocket money ranging from 1000 to 5000 rupees. The current study also negates the results of Ahmad, W. et al., 2013, who concluded that young students spend the major share of pocket money to purchase branded products. Surprisingly, a small number of respondents who owned lower "pocket money to buy brand products, responded that "money is not a hindrance" in building attitude and aims. The results of this study showed that the majority of the students spent 1000 to 3000 rupees on shopping every month.

This research concluded that students used to go shopping occasionally and a maximum number of students buy highend products like cosmetics after every 04 weeks. Since not all things are explicitly expressed constantly but researchers provide information to readers that assist them to figure out the real story, Analysis concluded that brand utilization has negative relation with the life satisfaction of universities students.

\section{LIMITATION AND STUDY FORWARD}

The research was limited to four Universities of Pakistan, three from Punjab Province (University of Sargodha, Bahauddin Zakriya University Multan, and Punjab University Lahore) and one from Capital city (Quaid-e-Azam University Islamabad). Data was collected through a convenient sampling method. The selection of students was limited to 385 students from four universities to find out the emerging tendency of brands utilization and its impacts on life satisfaction.

\section{RECOMMENDATIONS}

Recommendations are based on the results of this study; brand utilization has a significant negative association with the life satisfaction of university students. Therefore, universities may opt measures to change life style and enhancement of life satisfaction level of their students.

\section{AUTHORS' CONTRIBUTIONS:}

Abdul Waheed: Devise main idea, Abstract and Conclusion writing, Methodology, Use of SPSS, Graphical representation, Discussion, Data Analysis, and its interpretation.

Iqra Almas: Data Collection, Writing the introduction, working on literature, and plagiarism.

Laila Shafi: Data Collection, working on literature, writing references and after completion of research reviews the article.

Umme kalsoom: Data Collection, working on literature, writing references, and after completion of research review the article.

Kanwal Yasmin: Data Collection, Methodology, Data Analysis, Discussion, Working on Literature and Proofreading.

\section{REFERENCES}

1. Abbas, T., Abrar, M., Saleem, R., \& Iqbal, A. (2016). The relationship of life satisfaction with buying intention and brand behavior for global brand. European Journal of Business and Management, 8(31), 97-105.

2. Ahmad, W., Arshad, H. M., Sabir, R. I., \& Ashraf, R. U. (2013). Antecedents of purchase intention for foreign apparel products among Pakistani university students: Implications for market entry strategy. Middle-East Journal of Scientific Research, 16(9), 1255-1263. https://doi: 10.5829/idosi.mejsr.2013.16.09.12018

3. Akaka, M. A., \& Alden, D. L. (2010). Global brand positioning and perceptions: International advertising and global consumer culture. International journal of Advertising, 29(1), 37-56. https://doi.org/10.2501/S02650 $\underline{48709201026}$

4. Belk, R. W., 1985. Materialism: Trait aspects of living in the material world. Journal of Consumer Research 12(3), 265-280. https://doi.org/10.1086/208515

5. Butgel Tunal1, S. (2016). Study on the effect of use of luxury brand during the social identity projection of individuals. https://doi.org/10.7456/10603100/004 
6. Charles, K. K., Hurst, E., \&Roussanov, N. (2009). Conspicuous consumption and race. The Quarterly Journal of Economics, 124(2), 425-467. https://doi.org/10.1162/qjec.2009.124.2.425

7. Chang, C. C., Oh, R. R. Y., Le Nghiem, T. P., Zhang, Y., Tan, C. L., Lin, B. B. \& Carrasco, L. R. (2020). Life satisfaction linked to the diversity of nature experiences and nature views from the window. Landscape and Urban Planning, 2020, 103874. https://doi.org/10.1016/j.landurbplan.2020.103874

8. Gürhan-Canli, Z., Sarial-Abi, G., \& Hayran, C. (2018). Consumers and brands across the globe: research synthesis and new directions. Journal of International Marketing, 26(1), 96-117. https://doi.org/10.1509/j im.17.0063

9. Frey, B. S., Luechinger, S., \&Stutzer, A. (2010). The life satisfaction approach to environmental valuation. Annu. Rev. Resour. Econ., 2(1), 139-160. https://doi.org/10.1146/annurev.resource.012809.103926

10. Greenspoon, P. J., \& Saklofske, D. H. (2001). Toward an integration of subjective well-being and psychopathology. Social Indicators Research, 54(1), 81-108. https://doi.org/10.1023/A:1007219227883

11. Grossman, M., \& Rowat, K. M. (1995). Parental relationships, coping strategies, received support, and well-being in adolescents of separated or divorced and married parents. Research in Nursing \& Health, 18(3), 249-261. https://doi.org/10.1002/nur.4770180308

12. Halvorsen, I., \& Heyerdahl, S. (2006). Girls with anorexia nervosa as young adults: Personality, self-esteem, and life satisfaction. International Journal of Eating Disorders,39(4), 285-293. https://doi.org/10. 1002/eat.20248

13. Hartmann, P., \&Apaolaza-Ibáñez, V. (2012). Consumer attitude and purchase intention toward green energy brands: The roles of psychological benefits and environmental concern. Journal of business Research, 65(9), 1254-1263. https://doi.org/10.1016/j.jbusres.2011.11.001

14. Koehn, N. F. (2001). Brand new: How entrepreneurs earned consumers' trust from Wedgwood to Dell (p. 5). Boston, MA: Harvard Business School Press.

15. Laroche, F.R.S.C., Papadopoulos, N., Heslop, L., \& Bergeron, J. (2003). Effects of subcultural differences on country and product evaluations. Journal of Consumer Behaviour: An International Research Review, 2(3), 232-247. https://doi.org/10.1002/cb.104

16. Maggioni, I., Sands, S., Kachouie, R., \& Tsarenko, Y. (2019). Shopping for well-being: The role of consumer decision-making styles. Journal of Business Research,105, 21-32. https://doi.org/10.1016/j.jbu $\underline{\text { sres.2019.07.040 }}$

17. McKnight, C. G., Huebner, E. S., \& Suldo, S. (2002). Relationships among stressful life events, temperament, problem behavior, and global life satisfaction in adolescents. Psychology in the Schools, 39(6), 677-687. https://doi.org/10.1002/pits.10062

18. Milevsky, A., Schlechter, M., Netter, S., \& Keehn, D. (2007). Maternal and paternal parenting styles in adolescents: Associations with self-esteem, depression and life-satisfaction. Journal of child and family studies, 16(1), 39-47. https://doi.org/10.1007/s10826-006-9066-5

19. Mrad, M., \& Cui, C. C. (2020). Comorbidity of compulsive buying and brand addiction: An examination of two types of addictive consumption. Journal of Business Research, 113, 399-408. https://doi.org/10.1016/j.jbus res.2019.09.023

20. Oliva, A., \& Arranz, E. (2005). Sibling relationships during adolescence. European Journal of Developmental Psychology, 2(3), 253-270. https://doi.org/10.1080/17405620544000002

21. Paxton, R. J., Valois, R. F., Huebner, E. S., \& Drane, J. W. (2006). Opportunity for adult bonding/meaningful neighborhood roles and life-satisfaction among USA middle school students. Social Indicators Research, 79(2), 291-312.

22. Powdthavee, N., \& Vignoles, A. (2008). Mental health of parents and life satisfaction of children: A withinfamily analysis of intergenerational transmission of well-being. Social Indicators Research, 88(3), 397-422.

23. Proctor, C. (2014). Enhancing well-being in youth: Positive psychology interventions for education in Britain. Handbook of positive psychology in schools, 416-432.

24. Proctor, C., \& Linley, P. A. (2014). Life satisfaction in youth. Increasing psychological well-being in clinical and educational settings, 199-215.

25. Proctor, C. L., \& Linley, P. A. (2009). i Maltby, J.(2009). Youth life satisfaction: A review of the literature. Journal of Happiness Studies, 10(5), 583-630. https://doi.org/10.1080/17439760802650816

26. Saloumi, C., \& Plourde, H. (2010). Differences in psychological correlates of excess weight between adolescents and young adults in Canada. Psychology, Health \& Medicine, 15(3), 314-325. https://doi.org/10.1080/13548501003668711

27. Sithole, T. M., Chiliya, N., Maziriri, E. T., \& Mapuranga, M. (2020). Precursors of status consumption and life satisfaction: A case of smartphones among the Generation Y cohort. The Retail and Marketing Review, 16(2), 154-160. https://hdl.handle.net/10520/ejc-irmr1-v16-n2-a11

28. Suldo, S. M., \& Huebner, E. S. (2004). Does life satisfaction moderate the effects of stressful life events on psychopathological behavior during adolescence?. School Psychology Quarterly, 19(2), 93. https://doi.org/10.1521/scpq.19.2.93.33313

29. Suldo, S. M., \& Huebner, E. S. (2006). Is extremely high life satisfaction during adolescence advantageous?. Social indicators research, 78(2), 179-203. 
30. Suldo, Shannon M., E. Scott Huebner, Allison A. Friedrich, and Rich Gilman. "Life satisfaction." In Handbook of positive psychology in schools, pp. 45-54. Routledge, 2009.

31. USMAN, H., PROJO, N. W. K., WULANSARI, I. Y., \& FADILLA, T. (2021). The Impact of Life Satisfaction, Quality Consciousness, and Religiosity on Customer Switching Intention to Halal Cosmetic. Asian Journal of Business Environment, 11(3), 5-19. https://doi.org/10.13106/ajbe.2021.vol11.no3.5

32. Valois, R. F., Paxton, R. J., Zullig, K. J., \& Huebner, E. S. (2010). Substance abuse behaviors and life satisfaction among middle school adolescents. Adolescent and Family Health, 5(1), 27-37.

33. Valois, R. F., Zullig, K. J., Huebner, E. S., \& Drane, J. W. (2003). Dieting behaviors, weight perceptions, and life satisfaction among public high school adolescents. Eating disorders, 11(4), 271-288. https://doi.org/10.1080/10640260390242506

34. Veblen, T., \& Mills, C. W. (2017). The theory of the leisure class. Routledge. https://doi.org/10.4324/97813 $\underline{15135373}$

35. Viswanathan, M., Rosa, J. A., \& Harris, J. E. (2005). Decision making and coping of functionally illiterate consumers and some implications for marketing management. Journal of Marketing, 69(1), 15-31. https://doi.org/10.1509/jmkg.69.1.15.55507

36. Winkelmann, R. (2006). Parental separation and well-being of youths: Evidence from Germany. The Journal of Socio-Economics, 35(2), 197-208. https://doi.org/10.1016/j.socec.2005.11.008 